\title{
FOGTÖMÉS KOPTATÁSÁT SZIMULÁLÓ BERENDEZÉS TERVEZÉSE ÉS KIVITELEZÉSE
}

\section{DESIGN AND CONSTRUCTION OF EQUIPMENT FOR FILLING WEAR SIMULATION}

\author{
Nagy Sándor ${ }^{1}$, Forgó Zoltán ${ }^{2}$ \\ ${ }^{1}$ Sapientia-EMTE, Müszaki és Humántudományok Kar, Mechatronika szak IV. évfo- \\ lyam, 547367 Románia, Koronka 1C; Telefon:+40-265-208172, fax:+40-265- \\ 206211, sandor93@yahoo.com \\ ${ }^{2}$ Sapientia-EMTE, Müszaki és Humántudományok Kar, Gépészmérnöki Tanszék, \\ 547367 Románia, Koronka 1C; Telefon:+40-265-208172, fax: +40-265-206211, \\ zforgo@ms.sapientia.ro
}

\begin{abstract}
The wear and durability of the fillings has been examined by researchers for a long time. This is influenced by the composition of the filling and of the toothpaste, the size and quantity of particles contained therein. Because of the relatively slow wear of the fillings under normal usage a faster method will be more appropriate for evaluation purpose. This paper will present a lightweight equipment for accurate tooth brushing simulation, which should provide a stable fixing for the toothbrush and fillings, more over they must be easily replaceable.
\end{abstract}

Keywords: simulator, tooth brush process, filling.

\section{Összefoglalás}

A fogtömések kopását, tartósságát már rég vizsgálják a kutatók. A tömésanyagok összetétele mellett ezt leginkább a fogpaszta összetétele, a benne található szemcsék nagysága és mennyisége befolyásolja. Mivel a fogtömés aránylag lassan kopik normál használat mellett, ezért egy gyorsabb eljárás kidolgozására volt szükség: olyan berendezést dolgoztunk ki, amely a lehető legpontosabban szimulálja a fogmosás folyamatát. Ez a berendezés a fogkefe és a fogtömés stabil rögzítését is kell biztosítsa, de mindemellett ezek könnyen cserélhetőek is kellett legyenek.

Kulcsszavak: szimulátor, fogmosás, fogtömés.

\section{A feladat megfogalmazása}

A marosvásárhelyi Fogorvosi Egyetem hallgatói kerestek meg azzal a kéréssel, hogy szükséges lenne egy olyan berendezés tervezésére és kivitelezésére, amely képes fogtöméseken elvégezni a mosást, hogy meg lehessen állapítani a fogkrémek hatását különböző fogtömő anyagok esetén. További kérés volt, hogy állítani lehessen a tömés mechanikai terhelését a fogkefe által, illetve párhuzamosan két kísérlet lefolyása az eredmények mihamarabbi kiértékelését kell lehetővé tegyék.

Kézen fekvő volt az a megoldás, hogy a mosást akkumulátoros fogkefékkel végezzük el, viszont a legnagyobb probléma azzal volt, hogy a fogkefe akkumulátora nagyon hamar lemerült, nagyjából 10 perc használat után, és sokáig tartott a töltés, 
körül belül 8 órát vett igénybe. Az ebből adódó szaggatott müködés nagyon hátráltatta a kísérletet, és a kollégák azt szerették volna leginkább, hogy folyamatosan tudjon müködni a fogkefe. Továbbá feltétel volt, hogy a fogkefe feje a fogtömést $2 \mathrm{~N}$ erővel nyomja, mivel ez a legoptimálisabb a fogmosásra, így ezzel lesz a leghitelesebben szimulálva a fogmosás.

\section{A berendezés tervezése}

A tervezésnél próbáltunk arra törekedni, hogy hozzáférhető és könnyen megmunkálható anyagokat válasszunk. Végül az alumíniumra esett a választás, illetve némelyik alkatrész acélból készült. Gondolni kellett a könnyü fogpaszta és fogtömés cseréjére is, a szerkezet felépítését is leginkább ezek befolyásolták.

A fogtömés helyét egy vékony alumínium lap végén határoztuk meg, ezért mikor a fogkefe ezt nyomja, enyhén meghajlik. Ezt a meghajlást használtuk ki arra, hogy nyúlásmérő bélyegeket ragasztva a lapkákra, előzetes kalibrációval, meg tudjuk határozni ennek terhelését, amely $2 \mathrm{~N}$ kellett legyen.

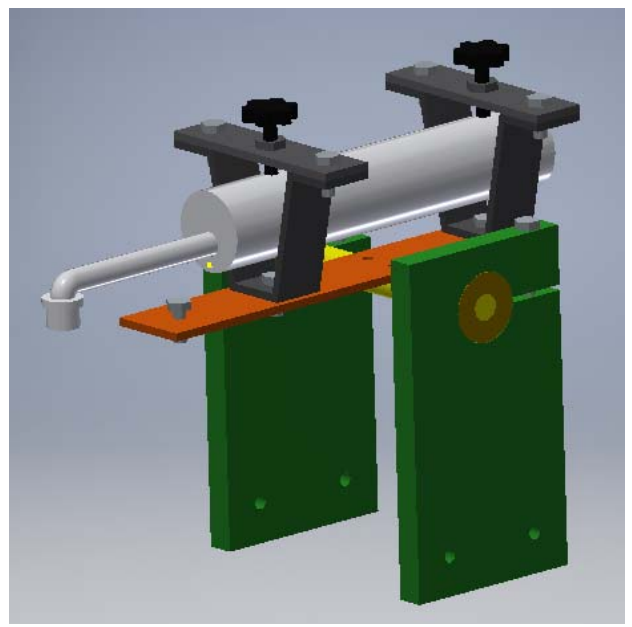

1. ábra. A fogkefe befogó szerkezete

\subsection{A fogkefe befogó szerkezete}

Az elektromos fogkefék motorja, illetve a fej mozgató mechanizmusa elég nagy és intenzív rezgéseket generál, ezért egy kompakt, merev, de egyben könnyen kezelhető befogó szerkezetre volt szükség. Ennek 3D modellje az 1. ábrán látható. Megfigyelhető, hogy a fogkefe két ,V” alakúra hajlított acéllemezbe van helyezve, majd ezekhez leszorítva. Ennek több elönye is van: a befogás merev, eltompítja a fogkefe rezgéseit, a csavarkötéseknek köszönhetően könnyen szétszerelhető, ha szükség van erre, illetve a „V” alaknak köszönhetően szinte bármilyen méretü és formájú fogkefe használható, ha esetleg egyik vagy másik meghibásodik. Ezek a tartók egy alumínium lapra vannak szerelve, ami egy kis tengelyen, erre merölegesen helyezkedik el. Ezen tengely körül a teljes befogó szerkezet elfordítható $180^{\circ}$ ot, így a fogkefe kivevése nélkül nagyon könnyen cserélhetö/pótolható rajta a fogpaszta. A tengely csapágyazása alumíniumtartókban van elhelyezve, olyan magasan, hogy a fogkefe könnyen el tudjon fordulni.

\subsection{A lapka befogása}

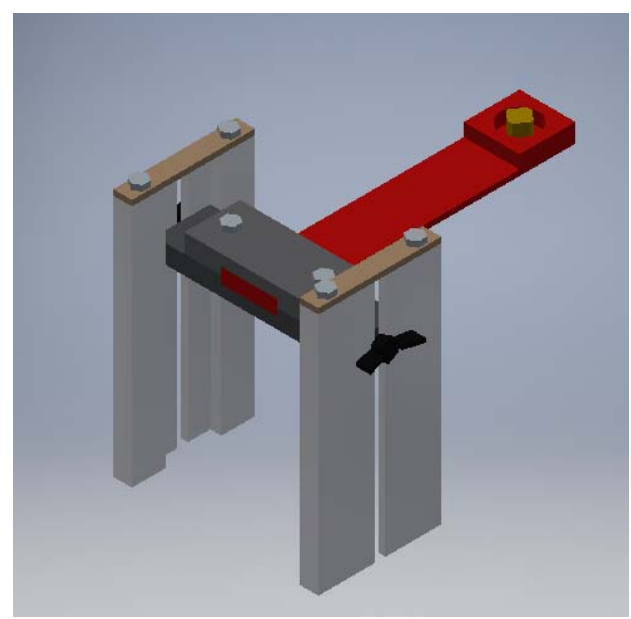

2. ábra. A lapka befogása 


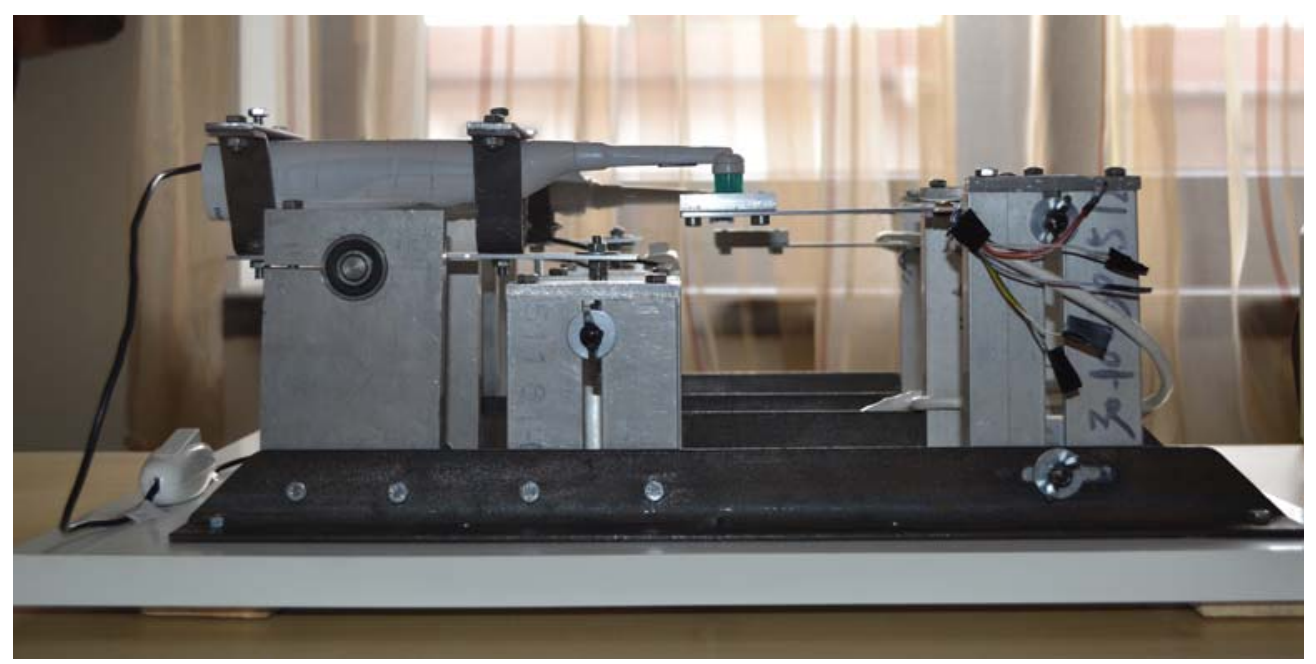

3. ábra. A teljes berendezés

A fogtömés egyforma szinten kell legyen a fogkefével, hogy a terhelés meröleges legyen a mintára, ezért ezt is tartóra kellett helyezni. Itt viszont gondolni kellett arra is, hogy a szerkezet állítható legyen, ezért a tartók sínekként is szerepelnek, amin a keresztben levő elemek csúsztathatók, illetve csavarral rögzíthetők. A lapka a két keresztben álló elem közé van beszorítva, ennek a végére pedig egy másik alkatrész van rögzítve, ami úgymond a fogtömés, a minta ,ágya". Ebbe a furatba gyurma lesz elhelyezve, majd ebbe lesz beágyazva a próbadarab, ami kellő stabilitást ad a mosás során.

\subsection{A mechanikai terhelés előállítása}

Annak érdekében, hogy a szimuláció a legjobban leutánozza az eredeti fogmosást, a fogkefe feje $2 \mathrm{~N}$ erővel kell nyomja a próbadarabot. Ezt nyúlás mérö bélyegek segítségével követtük, amelyek a próbadarabot tartó lapkára voltak ragasztva, és így mérni tudták a lapkák elhajlását a terhelés alatt. A fogkefét tartó berendezés merevséget kihasználva elég volt ezt mozgatni ahhoz, hogy a fogkefe is vele mozduljon. Egy lábakra erősített csavarral húztuk lennebb a befogó szerkezetet, egészen addig, amíg éppen $2 \mathrm{~N}$ erőt fejtett ki a próbadarabra. Természetesen, ezt a mérési folyamatot egy kalibrációs előzte meg, egy 200 grammos testet helyeztünk a próbadarabra, és lemértük a bélyegeken fellepő feszültségváltozást. Ezek után a megfelelő csavar segítségével annyira terheltük a mintát, hogy ugyanazt a feszültségszintet érjük el.

\section{Elkészítés}

A tervek elkészülését az alkatrészek legyártása és beszerzése követte, majd a berendezés összeállítását valósítottuk meg. A szerelés megkönnyítésére már a tervezés folyamán gondoltunk. Igyekeztünk nagyon sok hasonló alkatreszt tervezni, hogy ugyanabból az anyagból, ugyanolyan megmunkálások segítségével megoldható legyen a berendezés nagy részének az előállítása. Az ábrákról megfigyelhető az is, hogy ebből a berendezésből kettő készült el, két teljesen egyforma, mivel két elektromos fogkefe állt rendelkezésre, ezek pedig párhuzamosan, egymástól függetlenül tudtak müködni, ezzel is gyorsítva a fogtömések mosását. Miután mindennel elkészültünk és megtörtént az összeszerelése a berendezésnek, az 
egészet hozzácsavaroztuk egy fából készült talapzathoz. Ez plusz stabilitást ad a szerkezetnek, és megkönnyíti szállítását, ami szintén kitétel volt.

\section{A fogkefék folyamatos múködte- tése}

Mivel a mosás hatékonyságát és sebességét növelni kellett, mindkét fogkefét szétszedtük, kivettük belőle az akkumulátort, és a motor két csatlakozójára két szálat kötöttünk, melyeket egy állítható áramforrásból tápláltunk. Így pontosan be tudtuk állítani, hogy milyen feszültséggel müködtessük a fogkefék motorjait, mivel arra törekedtünk, hogy tökéletesen leutánozzuk a működését. Nem volt szabad sem gyorsabban, sem lassabban forognia a fogkefe fejének. A szükséges paramétereket még szétszerelés előtt lemertük. A tápegység mindig állandó feszültséget biztosított, amire az akkumulátor nem képes, ezzel is biztosítottuk a mosást, és ezáltal, a fogtömés kopásának az egyenletességet. Továbbá egy egyszerủ kapcsolót iktatunk be, ami megkönnyítette a berendezés ki- es bekapcsolást.

\section{Következtetések}

$\mathrm{Az}$ altalunk tervezett berendezés nagy hasznára válik majd a marosvásárhelyi Fogorvosi Egyetem diákoknak, ugyanis a kivitelezett berendezéssel a különbözö fogpaszták hatását fogják vizsgálni, hogy mennyire koptatják a különböző fogtöméseket, statisztikákat állítanak fel, így akar új, eddig nem ismert kutatási eredményre juthatnak. A bemutatott szerkezet tovább fejleszthetö, viszont jelen állapotban is teljesíti feladatát, kiértékelhető eredményekhez juttatja használóit.

\section{Szakirodalmi hivatkozások}

[1] Tolvaly-Roșca Ferenc: A számítógépes tervezés alapjai, Erdélyi Múzeum-Egyesület Kiadó, 2009.

[2] https://hu.wikipedia.org/wiki/Nyúlásmérö_bé lyeg

[3] http://www.esa-messtechnik.de/traveller_en 